DOI: 10.19085/journal.sijbpg030701

\title{
The impact of adopting e-government as a mechanism to enhance accountability as well as transparent conduct within public institutions
}

\author{
Tawanda Manenji \\ Midlands State University Gweru, Zimbabwe. \\ Barbra Marufu
}

Department Retail and Logistics Management, Midlands State University Gweru, Zimbabwe.

(c) Scholedge International Journal of Business Policy \& Governance (ISSN 2394-3351), Vol.03, Issue 07(2016) pg84-101. Published by: Scholedge R\&D Center [www.theSCHOLEDGE.org] [Email: editorial@thescholedge.org]

\begin{abstract}
This study examines the impact of adopting e-government as a mechanism to enhance accountability as well as transparent conduct within public institutions in Zimbabwe. There is a belief that egovernment brings about better change in governance issues through active disclosure of governance information. The research found out that e-government in Zimbabwe though still being nurtured, has better prospects and there is great need for clearly setting and meeting a conducive environment for it to flourish. That is a set of pre-requirements need to be assessed before trying to implement egovernment into full swing. Zimbabwe lacks an unanimous e-government strategy across its ministries hence the existence of disparities in e-government adoption within the country - some ministries are more advanced while others only exhibit the first initial stages of e-government. However, the adoption of e-government in Zimbabwe has been hampered by a plethora of challenges ranging from politics, economics, social and technological. Among them include inadequate or weak legislative frameworks guiding and directing e-government implementation, budget constraints, digital divide as well as technological incompetence. The study also makes some recommendations as to how egovernment prospects can be fully attained and such remedies among others include the passing of a comprehensive IT policy which cut across all government ministries, embracing Public Private Partnerships in building IT infrastructure, and redefining government's top priorities and focus much on e-government investment. The paper also notes the effects of poor governance to a country. Zimbabwe's e-government strategy if managed properly, would also reduce government external debt, improve service delivery, promote economic development, and increase public accountability and transparency within the public sector.
\end{abstract}

\section{Key Words}

Zimbabwe e-government

\section{Introduction and literature review}

E-government has become the most formidable issue globally, (UN, 2006; Heeks 2003). It has become a matter of debate in contemporary public administration with mixed feelings among authorities and some key stakeholders. The other strand is very optimistic about the merit of adopting an online mode of service provision whilst the other critical school of thought has questioned its merit and therefore has taken a cautious approach in adopting and implementing e-government development strategies in their respective regions. The optimistic school has argued that the prospects of adopting a digital 
government lies in its tenet of promoting good governance, that is its ability to enhance accountability, transparency, inclusiveness and democratic participation, among others, (Haldenwang, 2004; Heeks, 2003; OMOEFA, 2007). However, the critical approach to e-government alleges that embracing e-government would be detrimental to the existing state of public service delivery, (Wong and Welch, 2004). They perceive that adopting e-government would bring unwanted change (hence public authorities try to fight the change), they also argue that due to the digital divide challenge, egovernment can lead to uneven distribution of its perceived goodies. Moussa, and Schware, (1992) argue that even after adopting e-government there would still be need to uphold the old manual mode of service delivery due to the latter's inability to stand alone. It has to compliment the old 'manual' structure systems and processes hence regarded to be costly. E-government is argued not to be a perfect substitute of the old practices.

The need for transparency and accountability in public sector management has become a global challenge especially in the 21st century where the major objective of the Millennium Development Goals (MDGs) is to achieve good governance through a mutually shared state-citizen interaction. There is need to effectively monitor the administrative machinery of the government. Effective monitoring calls for "active disclosure" of governance information to key stakeholders like citizens, auditors and any other entity acting as a watchdog to public officers. A lot of governance information at citizens' disposal has meant that most parochial and participant citizens have to perform a monitoring role in matters of local, national, regional and international governance and politics, (OECD, 2003).

Traditional ways of information gathering, storage, processing and dissemination which were highly laborious have been believed to be lagging behind with the demands of the 21st century hence was the call to embrace digital government. E-government champions argue that embracing Information Communication Technologies (ICTs) is possibly one way to combat the challenges that were associated with the traditional administration. The use of ICTs is believed to have revolutionalized the public sector practices, processes and systems. Bekkers et al (2006:2) in support of this has this to say, "In many countries e-government has become the symbol of the way in which ICT has penetrated in the nerves of ministries, local and regional government and all kinds of agencies". Though this is the optimistic school' argument, the critical school of thought believe that unlike the traditional manual administration, online service provision cannot work independently of the later due to quite a number of factors such as change resistance, the digital divide, ignorance and inadequate forms of resources.

From the inception of an organization, various prescriptions and developments have been adopted inorder to help organizations operate effectively and efficiently, (Hughes, 2003). Organizational theory literature traced back from the traditional old administration to the new modernized electronic administration has been tailored to provide a cure for the ills of institutional management. Egovernment, which was prescribed by the New Public Management paradigm, was believed to make a valuable contribution to national development and enhancing transparency within the public sector. The concept of e-government rose to fame during the New Public Management era with proponents such as Hood (1991) arguing that it had capacity to deal with the existing inefficiencies that were prevalent in the public sector due to the manual collection, storage, processing, retrieval and dissemination of public information.

The more economically developed Western Europe and Asian countries first developed the concept and practice of e-government before it was contextually adopted by other continents, particularly Africa (OECD, 2003). E-government concept has been believed to be highly "preached" by the Western and Asian information technology leaders to "unrepentant" Africans for its adoption in the later have been cautiously embraced.

Adopting e-government would mean an implementation of management information systems (MIS) that is an essential element of effective monitoring and evaluation. These various MIS would combat 
chances of public officials embezzling public funds and also compel them to be accountable for their actions. Public officials have been accused of misusing and or embezzling funds as well as engaging in corrupt activities which has resulted in escalation of Zimbabwe's excessive sovereign debt.

After attaining political independence, most African countries intensified corruption levels and weakened their financial management systems, (Olowu 2002, DFID, 2010). This has strained their national budgets resulting in unmatched sovereign debts. To this regard, Zimbabwe, Mozambique, Malawi, Ghana, Cameroon and many other African countries had the same fate. Therefore, against this background, a diversity of key stakeholders ranging from the citizens, development partners, government employees, among others have been waiting to enjoy the merit of adopting digital government.

According to the World bank report (2004) it is believed that the potential of e-government as a developmental tool in both the developed and developing worlds hinges upon the three factors which are; technological infrastructure, human capital and electronic connectivity for all (UN egovernment survey report, 2003). Technological infrastructure includes having hardware such as computers, mobile phones and other ICT supporting devices that can either be information reservoirs or transmitters. The African plight in as far as this factor is concerned has been severe lack of hardwares. According to Strive Masiyiwa, a renowned telecomunications entreprenuer in Southern Africa, about $70 \%$ of the Africans had never heard a telephone ring in the early ninties.

Human capital consists of the able talented and skillful professionals who are either in the main technical field of ICTs or those who perform the administrative roles within the ndustry. According to Scott 2014, the greatest resource for any organisation is the internal resource, which is the mind. Therefore, the prospect of every organisation lies in its ability to unlock human capital for it is the human capital which governs the external resources. Africa has been struggling to come up with such minds. Technological geniuses have been sprunging out of the European, American and Asian continents. A senior lecturer at the University of Zimbabwe is of the view that the Africaner could have brilliant scientific ideas but may be incapacitated to showcase his ingenuity.

Electronic connectivity deals with the availability and cost of internets and other networking servers which enables easy flow of information. The 2014 UN e-government report reported that there was generally low ICT usage in Africa than any other continent. Heeks (2003) expressed great concern over the worrisome state of e-governance in Africa. Generally, IT usage in African urban areas was suboptimal and atypical in rural areas a decade ago (OECD, 2003). However, in some parts of the continent, particularly South Africa, Ghana, Morrocco, Uganda and Kenya, e-government development had a steady progress. According to the 2004 UN report, digital divide was still a major drawback to achieving an e-economy in most parts of Africa. It is either the cost of serfing internet is exorbitant or unavailability of such internets.

The critical values in the public sector revolves on accountability and transparency which the Ministry of Finance (MoF), (housing the ZADMO) has to uphold when carrying out its mandate. The centrality of the Ministry of Finance in the public sector financial management systems is because it is responsible for carrying out audits and issuing out financial statements and reports showing how each spending unit has used its appropriated vote. ZADMO is responsible for effectively and efficiently managing Zimbabwe's public debt and keeping it at optimum levels.

E-government's development in every state has to be legitimatized through a piece of legislation or policy directive or an official statement by the president as postulated by Harold Lasswell. Zimbabwe's e-government initiative has to be formally legitimatized through various pieces of legislation. There has to be a very broad national ICT policy giving a general guideline and direction on how the electronic platform can be beneficially implemented to meet citizens' needs. 


\subsection{Conceptual Frameworks}

\subsubsection{E-government}

E-government has been synonymously used with terms like modernized/online/digital governance, (Moon,2002; Sandoval and Gil-Garcia 2005). Just like the term e-Commerce, the term e-Government was born out of the Internet boom, (Horan and Gronlund, 2004). Kraemer, et al, (1978) postulated that e-government emerged in the late 1990s, but the history of ICTs and computing in government organizations can be traced back to the beginnings of computer history. E-government historical literature, traced back to the seventies conceptualized e-government as the use of ITs within government while recent e-government literature emphasizes the external use of IT such as services to the citizens, (Ho, 2002). E-government today involves issues such as decision making, service processes and values rather than mere automation, (Horan, 2004). E-government is defined by Heeks (2003) as the use of ICTs to improve the activities of public sector organizations - that is bringing the promise of greater efficiency and effectiveness of public sector operations. Another definition of egovernment was presented by United Nation's website, "to be e-government refers to the use of ICTs such as Wide Area Networks, the Internet, and mobile computing by government agencies". United States 2002 E-Government Act defines e-government as "the use by government of web-based internet applications and other information technologies, combined with processes that implement these technologies to;

a) Enhance the access to and delivery of government information and services to the public, other agencies and other government entities or,

b) Bring about improvements in government operations that may include effectiveness, efficiency, service quality, or transformation."

The World Bank postulates that these technologies can serve a variety of different ends: better delivery of government services to citizens, improved interactions with business and industry, citizen empowerment through access to information, or more efficient government management. The resulting benefits can be increased transparency and public accountabilit, less corruption, greater convenience, revenue growth, and/or cost reductions.

This study shall conceptualize e-government as governments' use of information communication technologies to offer for citizens and businesses the opportunity to interact and conduct business with government by using different electronic media such as telephone touch pad, fax, smart cards, self-service kiosks, e-mail and Internet. It is about how government organizes itself in its administration, rules, regulations and frameworks set out to carry out service delivery and to coordinate, communicate and integrate processes within itself.

\subsubsection{Information Communication Technology}

Information Communication Technology (ICT) is a diverse set of technological tools and resources used to communicate, and to create, store, manage and disseminate information. Zimbabwe National Information and Communication Technology Policy Framework (2005) defined ICT as a generic term referring to technologies that are used for collecting, storing, analyzing and exchange of information in various forms through various media. According to the Information Technology Association of America, IT can be defined as "the study, design, development, implementation, support or management of computer-based information systems, particularly software applications and computer hardware." IT specialists handle everything related to computers, including data storage, database administration, and all other aspects related to information storage, retrieval, transmittal, protection, and processing information securely, (http://www.ehow.com/about). ICT refers to technologies that provide access to information through telecommunications (http//www.techterms.com/definition). Wilson (1992:4) defined IT as, "it is the means by which science is used in the collection, storage, processing and movement of information". Shariful Islam and Nazmul Islam (2006:2) considered ICT as "the use and application of computers, telecommunications and microelectronics in the acquisition, storage, retrieval, transfer and dissemination of information". Therefore, this study will comprehend ICT as the application of communication technologies in information management. 


\subsubsection{Accountability}

Sinclair (1995:68) notes that accountability definition depends on the ideologies, motives and language of our times. He further noted that accountability has specific meanings, for instance "auditors discuss accountability as a financial matter, political scientists view it as a political imperative and legal scholars as a constitutional arrangement, while philosophers treat accountability as a subset of ethics". According to Olowu (1993:81) public accountability is "the requirement that those who hold public trust should account for the use of the trust to citizen or their representatives". He further observes that "public accountability signifies the superiority of the public will over private interests and tries to ensure that the former is supreme in every activity and conduct of a public official." Similarly, according to Laleye (1993:122), "public accountability refers to sanctions and procedures by which public officials may be held to account for their actions". From the above three definitions, it can be observed that accountability refers tothe notion that public officials should be held responsible for their actionswhile in office. The possibility of this reality requires that public officials be held responsible for their actions while in positions of authority and there must be certain norms and values that they shall be required to observe. Citizens should have the right to know what actions have been taken in their name, and they should have the means to force corrective actions when government acts in an illegal, immoral, or unjust manner. Individual citizens should have the ability to have some redress when their rights are abused by government or they do not receive the public benefits to which they are entitled.

\subsubsection{Transparency}

Richard W. Oliver (2004:31), in his book What isTransparency? wrote that transparency has come to mean "active disclosure." Other scholars have defined government transparency as "the publicizing of incumbent policy choices, and "the availability and increased flow to the public of timely, comprehensive, relevant, high-quality and reliable information concerning government activities." Transparency comprises not only the disclosure of government information, but also the access, comprehension, and use of this information by the public. Transparency, as such, requires a public that can acquire, understand, and use the information that it receives from the government. This can go on to mean that public officials have to display transparency in carrying out their respective duties such as procurement processes and the issuing of tenders. Adopting e-government can lead to more transparent conduct in this regard as argued by Francesco (2008).

\subsection{Theoretical Frameworks}

Scholars like Hughes (2003) thought e-government to be an element of the NPM theory. He argued that the concept of e-government was recommended by NPM theory since its main emphasis was hinged upon cost cutting and increased efficiency within the public sector. Therefore, the adoption of e-government was in a way trying to achieve a lean government structure by replacing manual mode of service provision with automation (OECD, 2003). For the purposes of this research, e-government models are going to be used to examine Zimbabwe's e-government development agenda. Quite a number of models have been formulated though this study shall be restrained to only three which are;

1. E-readiness models

2. E-government development models and,

3. E-government delivery models

\subsubsection{E-readiness models}

There are various e-readiness index models propounded by the United Nations, OECD, African Development Bank, Heeks, (2001), to name but a few. Basically the models seek to measure a country's preparedness to adopt and implement e-government programs and projects using the available resources. Some e-readiness models put much emphasis on the corresponding infrastructure and technology available while others put more emphasis on the human aspect and some on policy robustness. It has to be noted that a country's e-readiness index can be used to determine egovernment development phase in which a nation is. The International Telecommunication Union 
(ITU) identified a set of four broad conditions that should be met for a country's governance to be digital which are; (i) Infrastructure (ii) Policy (iii) Governance and (iv) Outreach

ITU's definition of infrastructure is multi-dimensional in the sense that nations are required to provide technical infrastructure such as the networks, energy power, skilled human capital, physical ICT gadgets like laptops, computers and mobile phones. Therefore, according to ITU, the effectiveness of e-government services in reaching citizens and businesses depends greatly in the availability of ICT infrastructure. Nations then need to assess the status and development of ICT infrastructure in their countries and be able to plan e-government projects accordingly.

Secondly, strategies and planning without execution is likened to hallucinating. After setting up goals, targets and milestones, the vision needs to be executed. The policy helps to guide and direct the egovernment development initiative. According to Heeks (2003), most developmental programs and projects tend to immaterialize because they lack a clearly formulated legal policy framework. After ensuring that the required infrastructure has been provided it is also crucial to regulate its application and monitor the private sector especially in public-private partnership arrangements as well as providing other ministries and departments a clear picture on how to help achieve the policy goals.

Thirdly, the aspect of governance is supposed to be considered before undertaking an e-government initiative. This means the performance of public administration is an important factor for the success of e-government initiatives. Basically, governance relate to how individuals and groups interact with their government, it is about relationships, links and networking. Commonly, it is recognized that a government performs well if it, at least, does not abuse its power, is not corrupt, and follows the due processes of law, which includes a division between the executive, legislative and judicial powers, and freedom of the press, (ITU, 2009).

Lastly is the aspect of outreach which basically relates to the supply of information and services to the citizens and business. According to ITU e-government practitioners need to bear in mind that the end goal of digital government is to be able to reach out to the citizens hence the need to specifically design programs and projects that can be at least usable by the locality. Mainly the goal is to overcome long distance and language barriers, as well as managing the perceived democratic deficit of the institutions. The UN e-government report emphasized the need to delimit such limitation through education and awareness campaigns in as far as ICTs are concerned. Figure 2.1 below is a synthesis of some of the crucial preconditions necessary for a society to be e-ready.

Figure 2:1 E-readiness Assessment Criterion

Proposed pre-conditions for an e-readiness assessment

1. Availability of frameworks and guidelines for e-Government and e-Governance

2. Availability of e-government policies, strategies and implementation

3. Availability of methods and tools for e-government research

4. Presence of participation, e-democracy and e-voting

5. One-stop government, electronic service delivery, mobile services

6. International and regional projects, case studies and best practice

7. Administrative process design and change, collaborative activities, legal interpretation

8. Availability of trust and security: provisions and instruments

9. Knowledge management, public information, decision process support

10. Interoperability and standards, semantic standardization

11. Change management and new organizational arrangements: public-private-partnerships, virtual teams.

12. Legal, societal and cultural aspects of e-government

13. International dimensions: cooperation, comparisons, networks

14. Teaching e-Government in schools and colleges 


\subsubsection{E-government Development Models}

E-government has evolved through four distinct phases where each stage follows the other, (Schelin, 2003). Each phase represents different levels of technological sophistication, citizen orientation, and administrative change, (Moon, 2002; Holden, Norris and Fletcher, 2003).It is important to clarify that in reality these stages are not necessarily mutually exclusive or progressive (Moon 2002; Sandoval and Gil-Garcia 2005). At every level technological sophistication has been continuously added, (Gil-Garcia J. R. and Martinez J. M. (2005).

Phase One: Information Presence

This calls for making the intentions and objective of the government known by developing an inclusive government website. The government, however, provides static information to the public (Moon, 2002) and communication is usually one way that is government to the citizens and business, (Heeks, 2003). The government will only provide information such as physical addresses where they can be contacted and official working hours as well as forms and applications to the public, economic reviews, corporate regulations for business and budgetary allocation and spending as reference for government agencies.

Phase Two: Interaction

At this stage there is basic interaction with the government, providing platforms for job application forms for the public, permits, licenses, submission of requests and approvals to the centre by local government officers, and provision of a more dynamic information. There is virtually two-way communication though no transaction will be taking place. The general public can communicate with the government through e-mails, sending queries, complains and comments through government blogs or national portals, (Cordella, 2007).

Phase Three: Transaction

There is direct interaction between government and relevant entities. It is mainly characterized by making it possible for stakeholders to transact online. This will include provision of services such as bill and fine payments, license renewal, aggregating opinion, online procurement, tax returns for businesses, cooperative budget preparations, etc, (Heeks, 2003; Cordella, 2007).

Phase Four: Transformation

This phase is when a nation seeks to achieve the true vision of e-governance, providing an integrated platform for government services to be totally transparent to businesses and citizens (Holden, Norris and Fletcher, 2003). Heeks pointed that the focus on this stage is to create virtual agencies where government information is readily available to allow a seamless interface to respective agencies involved in the transaction. Single government portals will provide access to a variety of services, (Cordella, 2007). However, this stage is only an ideal one since most e-government progressive countries have been associated with the third phase of e-government development, (Heeks, 2003).

Table 2.1 overleaf summarizes the above discussion.

However, it is crucial to note that at one point a country might have at least characteristics of all the four phases but it should be established which phase has got predominant exhibits, (Heeks, 2003). Stages may not be chronologically succeeding each other but may be concurrently developed across departments and sub-departments. 
Table 2.1: UN-ASPA Five Stages of E-Government

\begin{tabular}{|c|c|c|}
\hline STAGE & UN STAGE DESCRIPTION & SPECIFIC FEATURES \\
\hline Stage One & $\begin{array}{l}>\text { Emerging Web Presence } \\
>\quad \text { Sites serve as a public information } \\
\quad \text { source } \\
>\quad \text { Static information on the } \\
>\text { government is provided } \\
>\text { FAQs may be found } \\
\text { Contact information is provided }\end{array}$ & $\begin{array}{ll}\checkmark & \text { Telephone Numbers } \\
\checkmark & \text { Postal Address } \\
\checkmark & \text { Email Address } \\
\checkmark & \text { Services Offered; Mandate, } \\
& \text { Organizational Structure, FAQs, Related } \\
& \text { RAs }\end{array}$ \\
\hline Stage Two & $\begin{array}{l}>\text { Enhanced Web Presence } \\
>\quad \text { Access to specific information that } \\
\text { is regularly updated } \\
>\quad \text { A central government homepage } \\
\text { may act as a portal to other } \\
\text { department sites } \\
>\quad \text { Useful documents may be } \\
\text { downloaded or ordered online } \\
>\quad \text { Search features, e-mail and areas } \\
\text { for comments are accessible }\end{array}$ & $\begin{array}{ll}\checkmark & \text { Updated in the past } 1.5 \text { months } \\
\checkmark & \text { Forms are available (html, word, } \\
& \text { sometimes zip, pdf) } \\
\checkmark & \text { Search function / Site Map } \\
\checkmark & \text { Message Board / Feedback Form } \\
\checkmark & \text { Newsletters or Publications / Purchase } \\
& \text { Information }\end{array}$ \\
\hline Stage Three & $\begin{array}{l}>\quad \text { Interactive Web Presence } \\
>\quad \text { A National government website } \\
\text { frequently acts as a portal } \\
\quad \text { Users can search specialized } \\
\text { databases } \\
>\quad \begin{array}{l}\text { Forms can be downloaded and/or } \\
\text { submitted online }\end{array} \\
>\quad \begin{array}{l}\text { Secure sites and passwords begin to } \\
\text { emerge }\end{array}\end{array}$ & $\begin{array}{ll}\checkmark & \text { Downloadable Forms (pdf, zip) } \\
\checkmark & \text { Specialized Databases } \\
\checkmark & \text { On-Line Forms Submission } \\
\checkmark & \text { Interactive Elements e.g. Chat rom / } \\
& \begin{array}{l}\text { Forum / Discussion Board } \\
\checkmark\end{array} \\
\begin{array}{l}\text { User Log-in and Password (internal use } \\
\text { or public) }\end{array}\end{array}$ \\
\hline Stage four & $\begin{array}{l}\text { Transactional Web Presence } \\
\text { Users will be able to conduct } \\
\text { complete and secure transactions } \\
\text { online } \\
\text { The government website will allow } \\
\text { users to customize a portal in order } \\
\text { to directly access services based on } \\
\text { specific needs and priorities } \\
>\quad \text { Sites will be ultimately secure }\end{array}$ & $\begin{array}{ll}\checkmark & \text { Public Use Log-in and Password (NOT } \\
& \text { exclusive for internal use) } \\
\checkmark & \text { Secure On-Line Payment } \\
\checkmark & \text { Confirmation of request (e-mail } \\
\text { confirmation } \quad / \quad \text { acknowledgment } \\
\text { receipt) } \\
\checkmark & \text { Display of Security and Privacy Policy }\end{array}$ \\
\hline Stage Five & $\begin{array}{l}>\quad \begin{array}{l}\text { Fully Integrated Web Presence } \\
\text { Country provides all services and } \\
\text { links through a single portal }\end{array} \\
>\quad \begin{array}{l}\text { No defined demarcation between } \\
\text { various agencies and departments }\end{array} \\
>\quad \begin{array}{l}\text { All transactional services offered by } \\
\text { government will be available online }\end{array}\end{array}$ & 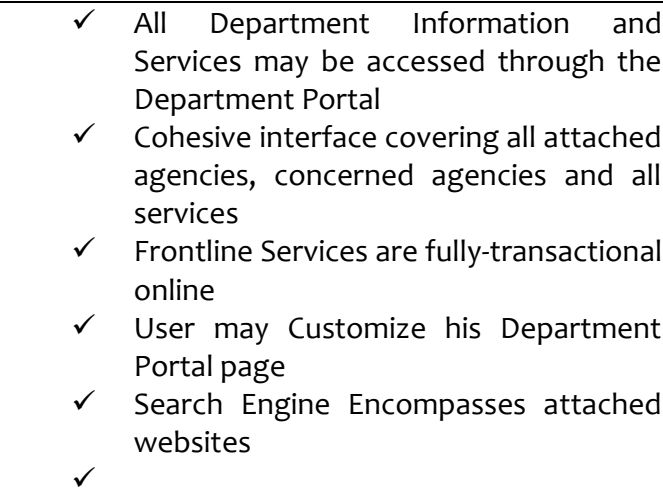 \\
\hline
\end{tabular}

Source: http://www.webopedia.com/TERM/S/SSL.html; Moon, (2002)

\subsubsection{E-government Delivery Models}

Popular e-government delivery models include government to citizens ( $G 2 C)$, government to business (G2B) and government to government (G2G), (Moon , 2002; Heeks, 2003). Analogous to e-commerce, which allows businesses to transact with each other more efficiently (B2B) and brings customers closer to businesses (B2C), e-government aims to make the interaction between government and 
citizens (G2C), government and business enterprises (G2B), inter-agency relationships $\left(G_{2} G\right)$ and Internal Efficiency and Effectiveness (IEE) more friendly, convenient, transparent, and inexpensive (United States' e-Government Strategy, 2003).According to World Bank, (2004:4) "any interaction of a governmental agency (G) with outside constituencies is called e-government...... outside constituencies can be citizens (C), businesses (B), or other governmental agencies ( $G$ ) themselves." As highlighted by table 2.2 below, e-government delivery model entails what and how government computer information systems and applications are linked with its stakeholders which are the business environment, other government agencies and the citizens at large.

Table 2:2 E-government delivery Model (Source: Heeks 2003:17)

\begin{tabular}{|c|c|}
\hline $\begin{array}{l}\text { Government } \\
\text { Government } \\
\text { (G2G) }\end{array}$ & $\begin{array}{l}\text { - } \text { public institution offering services to other public institutions. } \\
\text { - Eg Auditor General's office, which has regular process } \\
\text { interactions with ZADMO. Online systems to compile reports on } \\
\text { spending and revenues, information on contact details for staff } \\
\text { in other agencies, human resource matters. } \\
\text { - Less interactive processes, eg provision of information to other } \\
\text { public entities or public servants. }\end{array}$ \\
\hline $\begin{array}{l}\text { Government to Citizens } \\
\text { (G2C) }\end{array}$ & $\begin{array}{l}\text { - Offer bundled services to provide value to specific groups of } \\
\text { citizens who find themselves in prototypical "life situations". } \\
\text { - Requires most extensive national infrastructure and their } \\
\text { implementation will provide the biggest challenges to less } \\
\text { developed countries. }\end{array}$ \\
\hline $\begin{array}{l}\text { Government to Business } \\
\text { (G2B) }\end{array}$ & $\begin{array}{l}\text { - Cover all service interactions between an administration and the } \\
\text { private sector } \\
\text { - Typical areas include; customs, tax and revenues, procurement } \\
\text { and company registration } \\
\text { - Easier to implement because the private sector tends to have } \\
\text { access to a wider range of advanced technological } \\
\text { infrastructure the average citizen }\end{array}$ \\
\hline
\end{tabular}

Although there is a widespread agreement among academics, policymakers and the informed public that e-government essentially involves the use of electronic platform to deliver public services, there is no consensus on the merit of adopting digital government. Moon (2004) argued that though the citizens and the bureaucrats are keen to adopt e-government, they however, disagree on its merit to their respective welfares.

A multiple of benefits associated with the adoption of e-government range from increased efficiency, transparency, accountability, affordability and openness, (World Bank, 2004; EU, 2004; OECD, 2003). The adoption of online governments promote good governance and ensures that governments leapfrog towards enhancing transparency and accountability, (Haldenwang, 2004; Ruhonde et al, 2008). However, these benefits may come with a plethora of problems and daunting challenges of access and equity, (Butcher, 2006). In some parts of the world e-government has resulted in governments being tyrannical and unresponsive to the public, (Wong and Welch, 2004).

Wong and Welch (2004) introduced their essay by noting that, "Under the global pressure of information technology, the adoption of web based technologies in public administration has created a new government and-citizen interface...... however, whether e-government will unambiguously lead to a more transparent, interactive, open and hence, accountable, government remains a central question." Obijiofor and Inayatullah (1999)are of the opinion that while there is evidence of the usefulness of ICTs in many developed societies, questions of their appropriateness in a range of situations still remains. 
From Wong and Welch's argument, it can be deduced that one of the primary goals of adopting egovernment is to achieve good governance, with such tenets such as accountability, transparency, efficiency, and responsiveness. The resulting benefits can be lesscorruption, increased transparency, greater convenience, revenue growth, and/or costreductions, (United States'e-Government Strategy, 2003; Ruhonde, et al, 2008).

E-government often is thought to lead, almost invariably, to participation, by improving governmental transparency, expanding the information flow between governments and citizens, and enabling citizens to exercise more effective control of governmental institutions (UNESCAP 2006).

A UN report of 2012 reported that today's governments are partly digitalized which means that egovernment has become a global subject of concern. Haldenwang (2004) postulated that international actors have increasingly turned to e-government as a meansto promote good governance. E-government is viewed as an instrument to simultaneously increase the efficiency of public administration, that isimproving public service delivery andstrengthen the openness and transparency of political processes.

Hyden (1994) argued that in most African states there was a cancerous practice of maladministration and corrupt tendencies because of existing information asymmetries within the public sector. Ithas become a common belief among scholars that e-government has been used by nations to bail them out of their huge public debt as they help to minimize revenue pilferages through corrupt tendencies and poor procurement procedures and processes.E-government reform as argued by Heeks (2001) aim to address the shortcomingsof public management by applying management information systems. However, Heeks (ibid) noted that such progress, after many years of effort in implementing such reforms has been much more limited than expected. Implied here is that the merit of e-government has been overrated and as such, there is need to revisit the implementation process to give remedies where the process went wrong.

Heeks (2001:18) noted that e-government initiatives are frequently driven from outside government by vendors or by donors or by consultants. As a result, inappropriate systems are being forced in; systems from other sectors or countries that do not fit specific developing countries' realities.Mupanduki, (2013)quotingOkoli (1994) notedthat modern bureaucracy has been prematurely introduced into Africa, "....its values and institutions are, at present, inappropriate to Africans". According to him, modern concepts such as digital government cannot be readily adopted by African governments with their current infrastructuresincapacitated to embrace ICTs. It is believed that because of lack of awareness, knowledge, skills and confidence there is a generic lack of e-government leadership and commitment amongst senior public officials.

According to Matsiura (2009:9) governments may also use the Internet to distribute "disinformation" -- for example, by setting up Internet sites that appear to be operated by bona fide dissident groups but which are actually operated by government agents for the purpose of discrediting the real dissident organization or identifying its supporters."Critical success factors from e-government champions have to inform e-government development strategies in less economically developed countries. However, the central question of to what extent does e-government benefit the citizens and customers still remains a mystery.

It has to be noted that e-government has to be legitimatized through a piece of legislation. Egovernment requires an institutional context within which it can flourish, and its key components of an enabling context include public sector reform to improve service delivery, good governance and applying ICTs for development, (Abrahams and Newton-Reid2008)."The legitimation of technologies is based on formal regulations enacted by authorities..." Francesco (2008:252). Implied here is that behind every government decision or policy framework, there should be the backing up of the enabling acts and laws to legitimatize them. However, it can be one thing to have laws and acts 
enacted and to ensure there observation in surety. Most laws tend to be observed in "breach" than in "honour". In the light of the literature reviewed above, the following objectives were adopted:

\section{Objectives of the paper}

- To examine the merit of adopting e-government as a mode of public service provision

- To examine the extent of e-government in Zimbabwe

- To examine the challenges faced in adopting e-government in Zimbabwe

- To proffer possible solutions to problems faced and to recommend the possible way forward in the use of the ICTs in Zimbabwe.

\subsection{RESEARCH METHODOLOGY}

The research was a qualitative inquiry and hence employed qualitative methods of inquiry to answer the above and subsequent questions. The nature of this study required a methodology that would allow the researchers to do an in-depth assessment of the phenomenon being investigated. This is important especially considering that qualitative methods are deep and rich in meaning (Nueman; 2011) and therefore, make it possible to investigate the why, and how of decision making and not just the what, where and when, (Mupanduki; 2012). Thus, qualitative analysis of data involves nonstatistical or non-numerical organization of data in order to discover patterns, themes, forms and qualities found in field notes, interviews, transcripts, open-ended questions, diaries, etc. Within the scope of qualitative research, there is also the need to use a method that will create favorable conditions for the study to effectively answer the research questions. It is for this reason that the study focused on case study housed in the ministry of finance as the area of research.

Frankel \& Devers (2000) quoted in Mupanduki (2012) compounded that good qualitative studies answer clearly stated, important research questions, in order to focus and direct the goals of the study. Therefore, researchers pose such research questions to answer them to provide a better understanding of the issue (Cresswell 2009). Following this, the researchers developed the following research questions at the outset of this study from the extensive theoretical and conceptual frameworks covered in the literature review. The research questions posed are as follows:

1. What is the merit of adopting e-government in public service delivery?

2. How far has Zimbabwe progressed in e-government implementation?

3. What are the challenges faced and the possible solutions in implementing e-government policies in Zimbabwe?

4. What are the critical success factors and what can be recommended for the successful implementation of e-government adoption by the government of Zimbabwe?

\section{Research findings and discussions}

\subsection{E-government Regulatory Frameworks in Zimbabwe}

The findings revealed that e-government in Zimbabwe is a piece meal and a lot of work needs to be done in order to realize vision 2020 objective of a fully digitalised knowledge economy. ICT regulatory frameworks had been varriedlyAccording to the analysis, ICT policy needs to be robust and harnessing all government ministries and departments as well as clearly stating their respective key result areas (KRAs) in as far as e-government is concerned as it has been practiced in the Ugandan case.

\subsection{E-government prospect in Zimbabwe}

The research found out that bureaucratic pathologies, delays, undemocratic and wayward bureaucratic costs may be rectified by implementing an e-government reform. Also, it is believed that corruption and other host of mal administrative processes could be eradicated by embracing digital government. 
Therefore, by going digital the government of Zimbabwe will be in a better position to effectively coordinate its entire governmental functions as well as allowing HR transfers from one ministry to the other through a well-coordinated program.

The findings supported the notion that using the UN and WB e-government framework four major advantages of adopting e-government can be summarized as improved transparency, accountability, effectiveness (good governance) and decreased costs.

\subsection{The state of e-government in Zimbabwe}

The most visible e-government delivery model in Zimbabwe found in this research is $\mathrm{G}_{2} \mathrm{C}$ which had a $41.6 \%$ score, followed by $\mathrm{G}_{2} \mathrm{G}$ which has a $33.4 \%$ score and lastly G2B which has a $25 \%$ score. Figures 4.1 and 4.2 overleaf show the results of the opinion polling conducted by the researchers to determine the current e-government development models and stages respectively. A lot of government information is provided by government agencies, departments and ministries on the government web portal and also inter-ministerial web designs linking and connecting departments in single and or multiple government webs. Lastly, though less visible in the Zimbabwean context, virtual links between the government and the business world. That is mainly visible in contracting out and PPP arrangements with the corporate business world.

Figure 4.1 Approximated e-government delivery models in Zimbabwe

\section{Approximated e-government delivery models in Zimbabwe}

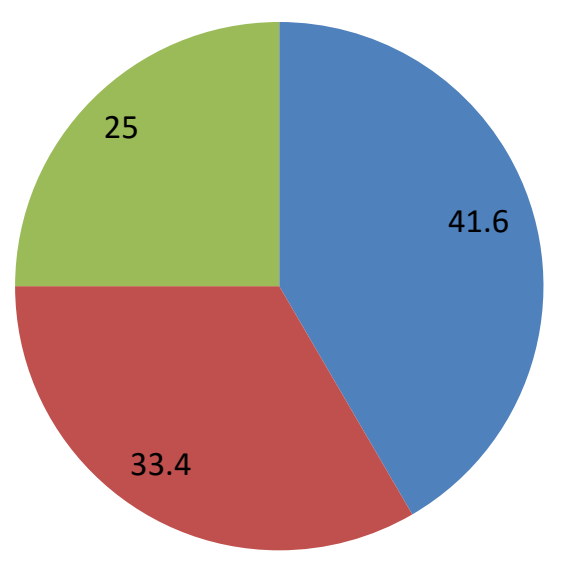

Government to Citizens

Government to Government

Government to Business 
Figure 4.2 Frequency distribution of respondents' opinion on Zimbabwe's e-government development stages

\section{Zimbabwe E-Government Development Stages}

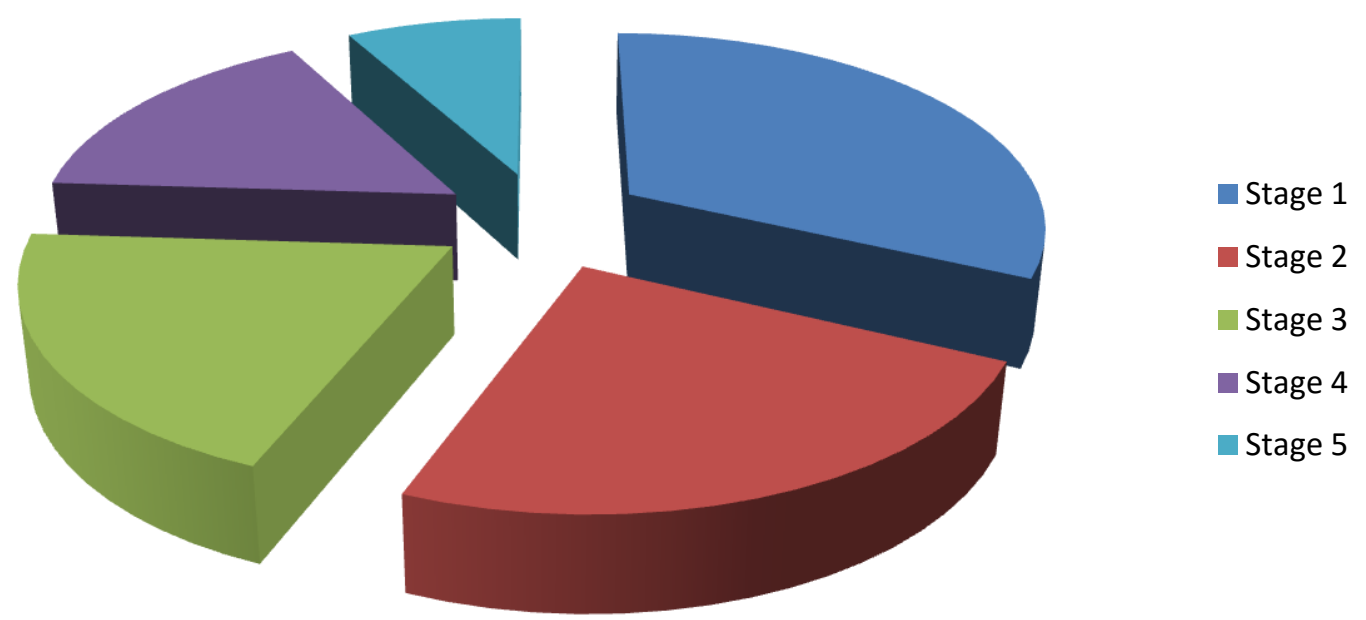

According to the findings of the opinion polling on the exhibition of features of a particular egovernment development stage shown in figure 4.2 , 32\% (8 out of 24 score) perceived that Zimbabwe is still on the initial stage, $24 \%$ ( 6 out of 24 score) on $2^{\text {nd }}$ stage, $20 \%$ ( 5 out of 24 score) on $3^{\text {rd }}$ stage, $16 \%$ ( 4 out of 24 score) on $4^{\text {th }}$ stage $8 \%$ ( 2 out of 24 score) on $5^{\text {th }}$ stage. A further analysis of these indicators shows that Zimbabwe is currently in the first two to the third stage of e-government development.

\subsection{E-government development challenge in Zimbabwe}

E-government has come along with a plethora of problems and among them include poor infrastructure, policy inadequacy, digital divide challenge, resource constrains, dedication and commitment challenge, lack of harmony among government ministries, budgetary constrains, etc. Ruhonde et al (2008) noted that the major challenges that stand in the way of e-government initiatives in Zimbabwe are lack of funding, rigid organization structures, poor ICT infrastructure, low ICT literacy rate, high human resource turnover, high impact of the HIV/AIDS pandemic and limited Public-Private Partnerships.

In an attempt to determine the extent of each challenge on the Zimbabwean e-government development agenda, an opinion polling was conducted with 24 of the respondents and the observations were recorded in figure 4.3 below. Major challenges ranked in their descending order are digital divide, budget constraints, resistance to change, organisational challenge, policy inadequacy, HR challenge and lastly, poor infrastructural developments. Ruhonde et al also explain how the HIV pandemic has greatly disturbed development initiative by depopulating the most able-bodied personnel as well as co-sharing available funds reserved for development to source HIV medicines. Also, according to the same authors, there is a frustratingly limited partnership between the public and the private sector due to a host of mostly political reasons. 


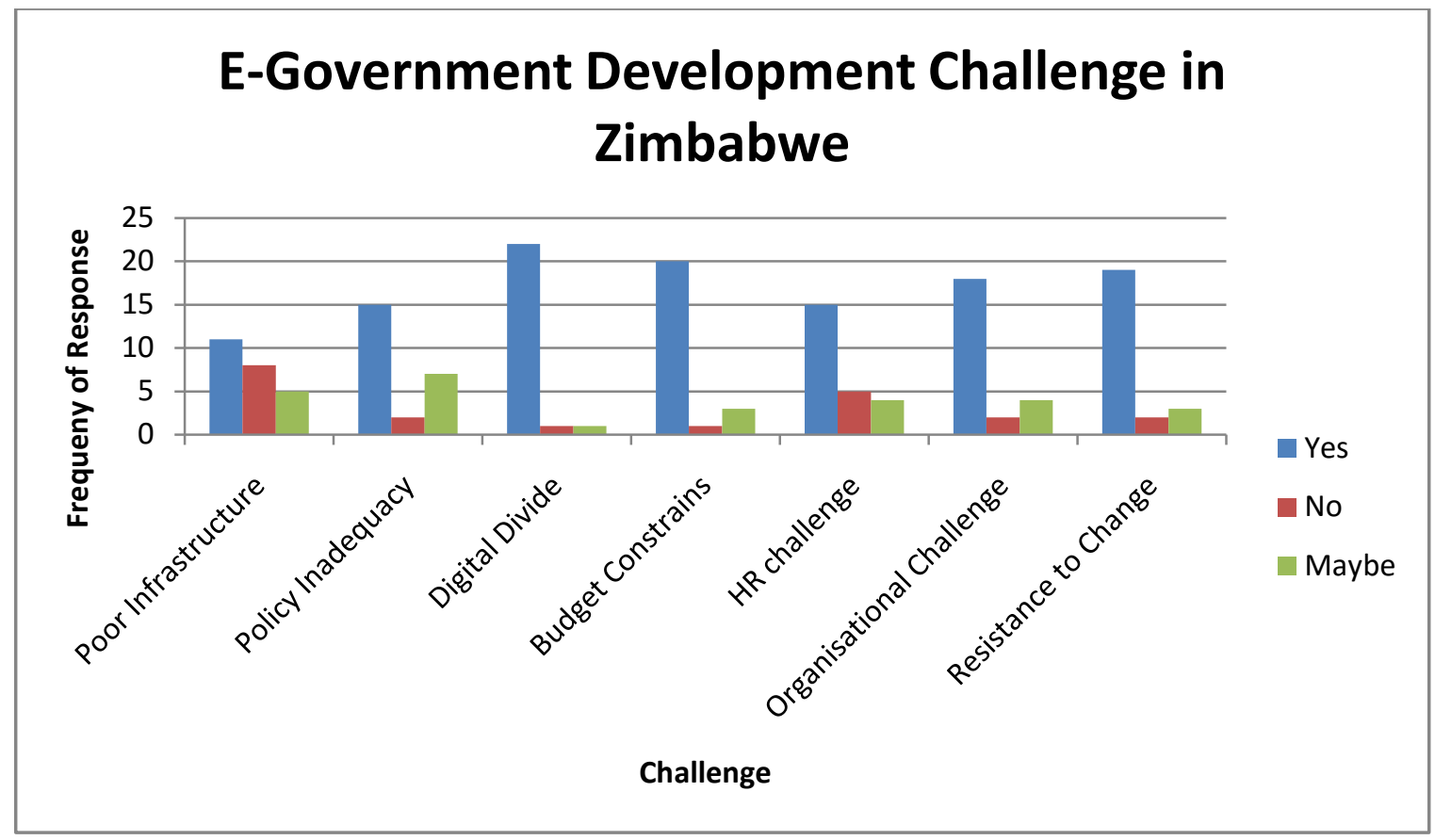

\subsection{Main Conclusions}

There are mixed feelings on the impact of e-government visa vis enhancement of public accountability and transparency within public institutions in Zimbabwe. Some believe e-government can help governments to leap frog towards good governance whilst others tend to be skeptical and cautiously embrace it as they fear the possible consequences of such change. It was also evident in this research that a few people still thought e-government to be a tool used to champion undemocratic interests of tyrannical governments by suppressing rights to governance information.

E-government in Zimbabwe has steadily developed from the foundations of the 1999 Nziramasanga Commission Report recommendations. In 2002, the Science and Technology Policy was crafted and implemented. Throughout the passage of time, e-government policy has either been upgraded or revised to the current National ICT Policy Framework of 2005- (see Table 4:1). Zimbabwe's overall ICT rankings point it to the late $2^{\text {nd }}$ and early $3^{\text {rd }}$ phase of e-government development (refer to chapter four; Figure 4:2). This is however, variedly applied since some government ministries and departments show characteristic features of either the $1^{\text {st }}$ or $2^{\text {nd }}$ phase of development.

The research also found out that Zimbabwe has benefited significantly as a result of embracing egovernment initiative. Increased bureaucratic efficiency, improved transparency and accountability, reduced bureaucratic costs and better governance are some of the benefits of adopting egovernment. Such benefits have been summarized in chapter four (refer to Table 4:2). However, a plethora of challenges has been hampering a smooth implementation of e-government reform. The list of challenges that are faced can be summarized into a PEST categorization meaning political, economic, social and technological challenges.

Politically, it was evident that before the 1999 Nziramasanga Commission Report there was little political will to embrace e-government call despite that a bulky of African countries like Morocco, Egypt, South Africa, Uganda and Mozambique had already put in place ICT policies in their respective nations. Today's ICT policy challenge is found on its failure to harness all other government departments and programs that is its failure to cascade down to other ministries and departments. A couple of years back, some political authorities in the opposition or ruling party deliberately failed to 
implement e-government strategies for political millage. Some didn't want the credit to be given to respective opposition heads in cases where the programs succeed.

Economically, national budget constrains coupled with less prioritization of e-government reform agenda has resulted in the ministry responsible for ICT allocated a piecemeal of the development funds. This is also evidenced by little researches on the subject that have been carried so far.

Socially, there is digital divide challenge where access to online services among rural dwellers is a great challenge. There is so uneven distribution of wealth, services and infrastructure between urban and rural dwellers. Also of importance is the resistance to change among individuals to uncertainties that a change might brought. Most bureaucrats are skeptical about adopting e-government which has delayed full realization of digitalized government in Zimbabwe.

Lastly but nevertheless the least is the technological challenge which has crippled e-government development in Zimbabwe. The existing technological infrastructure in Zimbabwe is worrisome if we are anywhere to go along with the ICT vision 2020. Zimbabwe has had experienced a brain drain record in the crisis period and if we are to achieve ICT policy goals it means there is need to lucratively invest in some form of technical expertise and infrastructure development.

That is following a well-crafted e-government strategy, a nation can enjoy a handful of benefits such as increased transparency, accountability, effectiveness and reduced costs due to resulting free flow of communication, effective participation and effective monitoring. Thecurrent e-government wave developed from the 2002 Science and Technology Policy which set the conditions for an effective and successful e-government strategy. Zimbabwe, however, is still a long way to fully enjoy the benefits of e-government since its legging behind in terms of infrastructure, policy, governance and outreach.

According to the international standards, Zimbabwe is overly grouped into the early $3^{\text {rd }}$ phase of egovernment development model where transactions such as rent paying, electricity bill paying and government procurements are done online. However, this is not uniform across all government ministries and departments, some tend to have features of the $4^{\text {th }}$ phase whilst others exhibit basics of either the $1^{\text {st }}$ or $2^{\text {nd }}$ phase of e-government development.

E-government can be an effective debt management tool in the sense that it ensures transparency and accountability hence reduced corruption and public funds' embezzlements by officials. It can also be an effective debt management tool in the sense that e-government facilitates cheap procurements by putting tenders on the global marketing. E-government also help co-ordinate extensive and complex government departments in single computer software that limit expenditures by flashing alert lights where spending pattern is likely to lead to overspending.

Various organizations such as the WB, ITU, UN and the ADB have come up with various set of conditions for e-government initiatives to flourish and among the following were their recommendations.

\subsection{Recommendations}

It is this study's humble submission that findings from this study can be used in policy formulation and intervention programs, particularly in PPP arrangements. Findings from this research show great prospects in e-government investment though absence of adequate resources has become a great challenge. This study therefore, recommends the following;

$\Leftrightarrow \quad$ Redefining government's top budget priorities and increased investment in ICT infrastructure. The policy community needs to push for an increased e-government attention into the policy circle. The government in supporting this has to set aside some funds to send some ICT students abroad especially to Europe, Asia and America to get hands on experience and later 
repatriate it back into Zimbabwe. This is called learning from other nations' experiences and has the advantage of using tried and tested e-government practices.

$\Leftrightarrow \quad$ Building PPP arrangements with international and local investors. Throughout history it has been agreed that governments are huge careless spenders on one extreme end whereas the private sector seeks to maximize profits and as such building partnerships between the two will bring about some form of moderation thereby increasing the efficiency of the public sector. The private sector will be providing infrastructure such as network boosters across the nation, providing some form of IT education, training and development in order to improve the current e-government status

$\Leftrightarrow \quad$ Making it compulsory to learn ICTs in primary and secondary schools that at least the population becomes IT literate and be able to meaningfully contribute to the policy formulation. According to Strive Masiyiwa on one of his facebook post, at least more than three quarters of rural schools have internet or at least a computer lab to learn basic computing. This will also help to curb today's resistance to change attitude among administrators since they will have the basic computer literacy.

$\Leftrightarrow \quad$ Increased awareness campaigns and public broadcasting e-government information. This will go a long way in conscientizing the population about the merit of using online services, the dangers as well as how best to effectively use online services.

\section{REFERENCES}

Abrahams, L. and Newton-Reid, L. (2008).E-governance for Social and Local Economic Development: Gauteng City Region perspective. LINK Public Policy Research Paper No.9, November 2008.

Bekkers, V.J.J.M. et al (2006).Information and Communication Technology and Public Innovation: Assessing the ICT-Driven Modernization of Public Administration. New IOS

Blakeley C. J. and Matsuura H. J. (2001).E-government: Is e-democracy inevitable? Alliance Law Group LLC; Westwood.

Bouwman, H., Van Den Hoof, B., Van De Wijngaert, L. and van Dijk, J. (2005). Information and Communication Technology in Organization.London; Sage.

Buchanan J. M. (1984).Politics without romance: Sketch of positive Public choice theory and its Normative implications. University of Michigan Press, Michigan.

Burrel, G. and Morgan, G. (1979).Sociological paradigms and organisational analysis: Elements of the sociology of corporate life. Ashgate, London.

Cordella, A. (2007). E-government: Towards the E-bureaucratic form? A journal of Information Technology (2007) 22, 265-274.Pelgrave, Macmillan.

Creswell, J. W. (2009). Research Design: Qualitative, Quantitative, And Mixed Methods Approaches.Sage; London.

Danziger, J. N. and Andersen, K. V. (2002)."The Impacts of Information Technology in Public Administration: An Analysis of Empirical Research from the "Golden Age" of Transformation."International Journal of Public Administration (25)5, pp.591-627.

Economic and Social Affairs. United Nations, New York.

DFID. (2010). Developing the Use of Information and Communication Technology to Enhance Teaching and Learning in East African Schools: Review of the Literature. www.educ.cam.ac.uk/centres-pdf.

EU (2004) eGovernment Research in Europe.European Commission. [http://europa.eu.int/information_society/programmes/egov_rd/text_en.htm] 
EU (2004b) IST eGovernment Research in FP6 (2003-2006).Introduction. [http://europa.eu.int/information_society/programmes/egov_rd/fp6/text_en.htm, (accessed Nov 15, 2014]

European Journal of Development Research, (16:2), 2004, pp. 417-432 - pdf.

Gil-Garcia J. R. and Martinez J. M. (2005) Exploring E-Government Evolution: The Influence of Systems of Rules on Organizational Action. National Center for Digital Government, SUNY.

Heeks, R. (2001). Understanding E-governance for Development. Institute for Development Policy and Management; Manchester.

Hill P. J. (1999). Public Choice.A Review. Gordon College, Boston

Ho, A. T.-K. (2002). Reinventing Local Government and the E-Government Initiative.Public Administration Review, (62)4, 434-444.

Holden, S., Norris, D. F.and Fletcher, P. D. (2003). “Electronic Government at the Local Level” Public Performance and Management Review.(26)4, pp. 325-344.

Hood, C. and Jackson, M.(1991).Administrative argument. Dartmouth, Brookfield

Horan, A. T. and Gronlund, A. (2004).Introducing E-Gov: History, Definitions, And Issues. Communications of the Association for Information Systems (Volume 15, 2004)713-729

Hyden, G. (1992).Governance and Politics in Africa. Lynne Rienner, Boulder.

International Telecommunication Union (2009).e-Government Implementation Toolkit: A Framework for e-Government Readiness and Action Priorities. ITU, [ available online at: http://www.itu.int/ITUD/cyb/app/e-gov.html Date accessed:16/01/15]

Kraemer, K. L., et al. (1978). Local Government and Information Technology in the United States.Paris: OECD Informatics Studies \#12.

Laleye, M. (1993). "Mechanisms for Enhancing Ethics and Public Accountability in Francophone Africa" in Rasheed S. and Dele Olowu, eds. Ethics and Accountability in African Public ServicesAddisAbaba: UNICA and AAPAM.

Layne, K., \& Lee, J., 2001, "Developing fully functional e-government: a four-stage model". In Government Information Quarterly, Vol. 18 pp.122-36

Manyeruke, C. and Phiri C.G. (2013).Complexities of transformation in Zimbabwe.OSSREA; Harare.

Moon, M. J. (2002).The Evolution of E-Government Among Municipalities: Rhetoric or Reality? Public Administration Review 62(4): 424-433.

Moon, M. J. and Welch, E. W. (2004).Same Bed, Different Dreams?: A Comparative Analysis of Citizen and Bureaucrat Perspectives on E-Government.Proceedings of the 37th Hawaii International Conference on System Sciences.

Moussa, A. and Schware, R. (1992), 'Informatics in Africa'.World Development 20(12):1737-1752.

Mupanduki, M. T. (2012). An analysis of the nature of and remedies for corruption in Sub-Saharan Africa: Focusing on Zimbabwe. PHD Thesis

Neuman, L. (2011).Social Research Methods: Qualitative and Quantitative Approaches. Pearson, Boston.

Ngulube, P. (2004).The nature and accessibility of e-government in sub-Saharan Africa. University of Kwazulu Natal, KZN. [Accessed online at http//www.africainfoethics.org on 28/10/14]

Obijiofor, L. And Inayatullah, S (1999).Impact of New Information and Communication Technologies (ICTs) on Socio-economic and Educational Development of Africa and the Asia-Pacifice: Private, A pilot study-pdf.

OECD (2003) The e-Government Imperative. Paris: OECD e-Government Studies. ISBN 92-64-10117-9 
OECD (2003), The e-Government Imperative. Paris: OECD e-Government Studies. ISBN 92-64-10117-9 OECD questionnaire, (2007).E-Government as a Tool for Transformation. [Available at http://www.olis.oecd.org/olis/2007doc.nsf (Retrieved February 14, 2014]

Olowu, D. (1993).The African economic crisis and the governance question. International Centre for Economic Growth, Abidjan.

Patton, M. Q. (1990). Qualitative evaluation and research methods.Sage; Newbury Park.

Press Publication; Amsterdam.

Richard, W. O. (2004). What is Transparency? McGraw-Hill, Nashville

Ruhode, E., Vesper, O and Maumbe, B. M. (2008).Arguing for the Enhancement of Public Service Efficiency and Effectiveness Through e-Government: The Case of Zimbabwe. IST Publications, Cape Town.

Rwangoga, N.T \&Baryayetunga, A. P. (2007) 'E-government for Uganda: Challenges and Opportunities', International Journal of Computing and ICT Research, Vol. 1.

Schelin, S. H. (2003). E-Government: An Overview. Public Information Technology: Policy and Management Issues. G. D. Garson. Hershey, PA, Idea Group Publishing: 120-137.

Shariful, I. M. and Nazmul, I. M. (2006). Information and Communication Technology (ICT) in Libraries: A New Dimension in Librarianship. Asian Journal of Information Technology, 5(8), 809-817 pdf.

Sinclair, A. (1995). The Chameleon of Accountability: Forms and Discourses. Accounting organizations and Society, 20 (2), 219-237 - pdf.

Stake, R. E. (1995).The art of case study research.Sage; Thousand Oaks.

UN Report: UN E-government Readiness Report 2004

UNDESA (2003).UN Global eGovernment Survey 2003. United Nations Department of

United States 2002 E-Government Act

Von Haldenwang, C. (2004).Electronic Government (E-Government) and Development: The Wilson, B. (1992). Information Technology: The Basics. London: Macmillan.

Wong, W. and Welch, E. (2004).Does E-Government Promote Accountability? A Comparative Analysis of Website Openness and Government Accountability

World Bank (2004).Building blocks of e-government: Lessons from developing countries. World Bank, New York. 